\title{
On-Farm Evaluation of Multipurpose Tree/Shrub Species for Sustaining Productivity in Alley Cropping
}

\author{
Abrham Tezera Gessesse ${ }^{1}$, Hailie Shiferaw Wollea ${ }^{2}$ \\ ${ }^{1}$ Senior Researcher, Natural Resource Management, Debre Birhan Agricultural Research Center, ETHIOPIA \\ ${ }^{2}$ Researcher, Forestry, Debre Birhan Agricultural Research Center, ETHIOPIA
}

\begin{abstract}
Alley cropping is a system in which strips (alleys) of annual crops are grown between rows of trees or shrubs, resembling hedges. Alley cropping is one of promising agro forestry practice to sustain productivity in highly populated areas where landholding sizes are very small and inorganic fertilizer use is very low. This study has been carried out with the aim of evaluating the effect of selected multipurpose tree/shrub species on yield performance of Teff (EragrostisTeff) through green manure application of hedgerow planting. Four different multipurpose tree/shrub species (Sesbania sesban, Croton macrostaychus, Cacia species and Cajuns cajun) seedlings were used and planted in two rows within the space of $8 \mathrm{~m}$ between avenue and $0.25 \mathrm{~m}$ within avenue and the trial was designed as Randomized Complete Block Design with three replications. Leaf biomass was incorporated to the soil in early July (1-2 weeks before sowing) as green manure. At each plot $15 \mathrm{~m}^{2}(3 \mathrm{~m} \times 5 \mathrm{~m})$ areas were laid for Teff (EragrostisTeff) grain and straw yield parameter measurements. The result shows that significantly higher grain and straw biomass yield of Teff (EragrostisTeff) were obtained through application of Sesbania sesban and Croton macrostaychus green manure as compare to Cajuns cajun and Cassia species. Leaf nutrient concentrations of $\mathrm{N}$ and $\mathrm{P}$ were found higher in Sesbania sesban than the rest of tree/shrub species. For this reason, farmers are advised to use Sesbania sesban and Croton macrostaychus species for Teff production in alley cropping agroforestry system.
\end{abstract}

Keywords: Alley cropping, Agroforestry, Teff (EragrostisTeff) yield, and MPTs

\begin{tabular}{|c|c|c|}
\hline $6 / 30 / 2015$ & Source of Support: Nil, Conflict of Intere & t: None Declared \\
\hline $\begin{array}{l}\text { How to Cite: } \\
\text { Cropping. Mal }\end{array}$ & $\begin{array}{l}\text { Gessesse AT and Wollea HS. (2015) On-Farm Evaluation of Multipurpose Tree/Shrub Species for Sustaining Pro } \\
\text { aysian Journal of Medical and Biological Research, 2(1), 31-34. }\end{array}$ & \\
\hline
\end{tabular}

\section{INTRODUCTION}

In the past half century, Ethiopia has about $40 \%$ total area was believed to be covered by natural forest which was rich in wild plants and animals; most agricultural lands were highly productive without external inputs; mountainous and hilly areas were covered with vegetation and soil; the surface water resources were at better status and the climatic condition of the country were accord to produce ample yield to feed the existed population. However, all these environmental and natural resources of the country are and will be historical legacy to this and/or the coming generation.

In early decades only $2.5 \%$ remain in the total area of the country is covered by natural forest; most agricultural land either remain as waste land or need more inputs; most mountainous and hilly areas lost all its biological resource and soil; most waters bodies either dried or shrieked and polluted and finally the climatic condition influence negatively on productivity. These problems are series in northern, southeast, and central highland parts of Ethiopia.

One of the crux reasons for these problems is miss resource exploitation and inappropriate production system, which ignore the concept of sustainability and ecological impact. Hence, it requires the transition to practice that are more environmentally sound and have the potential for the contribution to long-term sustainability (Stephen R.G., 2000).

The traditional agricultural system is targeted on expansion of cultivation land to increase productivity, which caused land shortage and natural resource degradation. In other hand, the modern specialized agricultural system carry out production function only by adding large auxiliary energy inputs (fertilizer and pesticides) and paying little attention to environmental degradation and human health risks. To minimize these negative tendencies, it is necessary to run a sustainable agro ecosystem that is environmental sound agricultural system. 
Agro forestry is one option of sustainable agro ecosystem-based production system (Menfes T., 2003). Appropriate agro forestry system assumed that, can provide the environmental function needed to ensure sustainability and maintain microclimate and other favorable influences (Nair P.K.R., 1993);practical way to mimic the structure and function of natural ecosystem (Menfes T., 2003), control soil erosion and increase soil fertility (Young A., 1989). These authors reported that in the humid and sub-humid tropics alley cropping is one of promising agro forestry practice to sustain productivity. Therefore, the virtues of alley cropping agroforestry systems to sustain productivity require evaluation of a given agro forestry practice and selected multipurpose shrub species in terms of contribution of yield performance of Teff (EragrostisTeff) through green manure application.

\section{Materials AND Methods}

\section{Description of the Study area}

The study area is located on $9^{\circ} 51^{\prime} \mathrm{N}$ latitude and $39^{\circ} 45^{\prime} \mathrm{E}$ longitude at an elevation ranges between 1500 and 2300 meter above sea level, Armania district, Northern Shewa Zone, Amhara Region, Ethiopia. The area is characterized by rough topography, dense population, subsistence agricultural practice and ideal area for agro forestry practice. The climate of the study area is weynadega (sub-tropics) with annual rainfall distribution ranges from $1500-2000 \mathrm{~mm}$, and minimum and maximum temperature ranges from $0-9{ }^{\circ} \mathrm{C}$ and $15-25^{\circ} \mathrm{C}$, respectively. The soil depths of the study area reach approximately $1.2 \mathrm{~m}$ with surface textural class (upper $0.2 \mathrm{~m}$ ) clay and $6.93 \mathrm{soil} \mathrm{pH}$.

\section{Experimental design and data collection procedure}

The experiment was established during 2004 with four different multipurpose tree/shrub species (Sesbania sesban, Croton macrostaychus, Cacia species and Cajuns cajun) were used for alley cropping agroforestry with most local people used for stable food crop consumption which is called Teff (EragrostisTeff). The trial was designed as Randomized Complete Block Design (RCBD) with three replications. The selected multipurpose tree/shrub species planted on a plot area of $5 \mathrm{~m}$ by $8 \mathrm{~m}\left(40 \mathrm{~m}^{2}\right)$. In each plot, seedlings were planted in two rows within the space of $8 \mathrm{~m}$ between avenue and $0.25 \mathrm{~m}$ within avenue. When the tree/shrub species attain height of $2 \mathrm{~m}-3 \mathrm{~m}$ with $2 \mathrm{~cm}-3 \mathrm{~cm}$ of Diameter Burst Height(DBH), they were cut at $0.25 \mathrm{~m}$ above the ground and chopped all the twigs and of the shrubs and incorporated with the soil. Leaf nutrient content, leaf biomass of multipurpose tree/shrub species and Teff grain and straw yield collected. At each plot $3 \mathrm{~m} \times 5 \mathrm{~m}\left(15 \mathrm{~m}^{2}\right)$ were laid for Teff (EragrostisTeff) grain and straw yield parameter measurements. Grain yield of Teff was measured by harvesting from all plants within the net plot area $15 \mathrm{~m}^{2}$. Threshing of Teff done manually cleaned and weighed the grain yield. Teff straw biomass was estimated from the net plot area straw yield by sun dried out the moisture content lost.

\section{Data analysis}

Analyzes of Variance were tested using SAS (version 9.0). The grain yield and biomass of Teff (EragrostisTeff) and leaf nutrient content of multipurpose tree/shrub species data subjected to one-way ANOVA using General Linear Model (GLM) procedures. Mean separation of treatments was carried out using LSD at 5\% probability level.

\section{RESULTS AND Discussion}

\section{Leaf biomass and Leaf nutrient content}

The planted multipurpose tree/shrub species biomass indicated that (Table I), the highest leaf biomass production was obtained from Sesbania sesban (47.36 ton $\mathrm{ha}^{-1} \mathrm{yr}^{-1}$ ) (biomass defined as the weight of the tree/shrub species pruning applied to the soil).Whereas, Croton macrostaychus gave least leaf biomass as compare to Cajuns Cajun and Cacia species. The present study supported by other finding like alley cropping of Faideherbiaalbida and Leucaenaleucocephala gave an average yield of 6.18 ton ha ${ }^{-1}$ mulch biomass for Leucaenaleucocehala and 0.97 ton ha ${ }^{-1}$ for Faidherbiaalbida (Chamshama S.A. et al 1998; (Lulandala L.L. et al., 1995). On the other hand, mulch production by Croton macrostaychus was much lower because of the slow growth performance of the tree as compared to the rest species.

Table I: Leaf biomass production potentials and leaf nutrient content of different multipurpose tree/shrub species at Armania district, North Shewa zone, Ethiopia

\begin{tabular}{l|c|c|c}
\hline \multirow{2}{*}{ Species } & $\begin{array}{c}\text { Leaf biomass } \\
\left(\mathrm{kg} \mathrm{ha}^{-1} \mathrm{yr}^{-1}\right)\end{array}$ & \multicolumn{2}{|c}{ Leaf nutrient content $(\%)$} \\
\cline { 3 - 4 } & & $\begin{array}{c}\text { Total } \\
\text { nitrogen }\end{array}$ & $\begin{array}{c}\text { Available } \\
\text { phosphorus }\end{array}$ \\
\hline Sesbania sesban & 47360 & 16.55 & 4.2 \\
Cacia species & 4506.8 & 7.46 & 3.4 \\
Cajuns cajun & 2752 & 14.64 & 3.6 \\
Croton macrostaychus & 293.2 & 11.95 & 3.2 \\
\hline
\end{tabular}


As shown in Table I, leaf nutrient content of Sesbania sesban had highest total nitrogen and available phosphorus as compared to the other multipurpose tree/shrub species treatments. The lowest total nitrogen and available phosphorus leaf nutrient content observed on Cacia species and Croton macrostaychus respectively (Table I). The author Legesse N. 2002 reported that leaf nutrient concentrations of nitrogen and phosphorus were significantly higher in non-nodulated than in the nodulated.

\section{Grain and straw yield of Teff(EragrostisTeff)}

The result indicated in Table 2 that, there was a significant difference ( $\mathrm{p} \leq 0.05$ ) between treatments on grain yields of Teff. In the beginning, application of multipurpose tree/shrub species green manure response on Teff grain and straw yield was not significantly different between treatments. After second year, application of selected multipurpose tree/shrub species green manure response on both Teff grain and straw yield, a significant difference was observed between treatments.

Table 2: Effect of alley cropping of selected multipurpose tree/shrub species on grain and straw yield of Teff at Armania district, North Shewa zone, Ethiopia

\begin{tabular}{|c|c|c|c|c|c|}
\hline \multirow[b]{2}{*}{ Year } & \multirow[b]{2}{*}{$\begin{array}{c}\text { Yield } \\
\left(\mathrm{Kg} \mathrm{ha}^{-1}\right)\end{array}$} & \multicolumn{4}{|c|}{ Treatments } \\
\hline & & $\begin{array}{c}\text { Sesbania } \\
\text { sesban }\end{array}$ & $\begin{array}{c}\text { Croton } \\
\text { macrostaychus }\end{array}$ & $\begin{array}{l}\text { Cajuns } \\
\text { cajun }\end{array}$ & $\begin{array}{l}\text { Cacia } \\
\text { species }\end{array}$ \\
\hline \multirow[t]{2}{*}{ Year 1} & & & & & $477.3^{\mathrm{a}}$ \\
\hline & & & 257 & $3280.3^{a}$ & 1949 \\
\hline \multirow[t]{2}{*}{ Year 2} & & & 1274 & $963.3^{b}$ & $861.3^{b}$ \\
\hline & & 5755 & $4292.7^{\mathrm{ab}}$ & $3459.0^{\mathrm{b}}$ & $2716.7^{\mathrm{b}}$ \\
\hline \multirow[t]{2}{*}{ Year 3} & & $1315.3^{\mathrm{a}}$ & $687.3^{\mathrm{b}}$ & $510.0^{\mathrm{b}}$ & 497.7 \\
\hline & & $4596.0^{\mathrm{a}}$ & 203 & $1668.0^{\mathrm{b}}$ & 1513.7 \\
\hline \multirow[t]{2}{*}{ Year 4} & & $800.67^{a}$ & $682.7^{\mathrm{a}}$ & $409.67^{\mathrm{b}}$ & $429^{b}$ \\
\hline & Straw & $1884.7^{\mathrm{a}}$ & $1678.3^{\mathrm{a}}$ & $831.7^{\mathrm{b}}$ & $905^{\mathrm{b}}$ \\
\hline
\end{tabular}

Rows with the same letters subscription are not significantly different ( $\mathrm{p} \leq 0.05)$.

Teff grain yield in two subsequent cropping seasons substantially increased as compared to the rest cropping season. This may be related to high rainfall in subsequent years. Grain and straw yield of Teff was highly affected by the application of green manure of Sesbania sesban and Croton macrostaychus (Table 2). However, Teff grain and straw yield was little affected by Cajuns Cajun and Cacia species in the subsequent four years. The decline in Teff grain and straw yield may be attributed to competition for moisture, shade effect, rainfall pattern and nutrients between tree/shrub species and crops (Lawson T.L., and Kang B.T., 1990; Akonde T.P. et al., 1996 and Lainher D.E. et al., 1996).

\section{Mean Annual of Teff yield}

Four year alley cropping trial conducted at Armania district, Northern Shewa, Ethiopia on a clay soil showed that (Fig 1), using Sesbania sesban and Croton macrostaychus pruning Teff grain and straw yield could be increases at a reasonable level.

Fig 1: Mean annual grain and straw yield of Tef

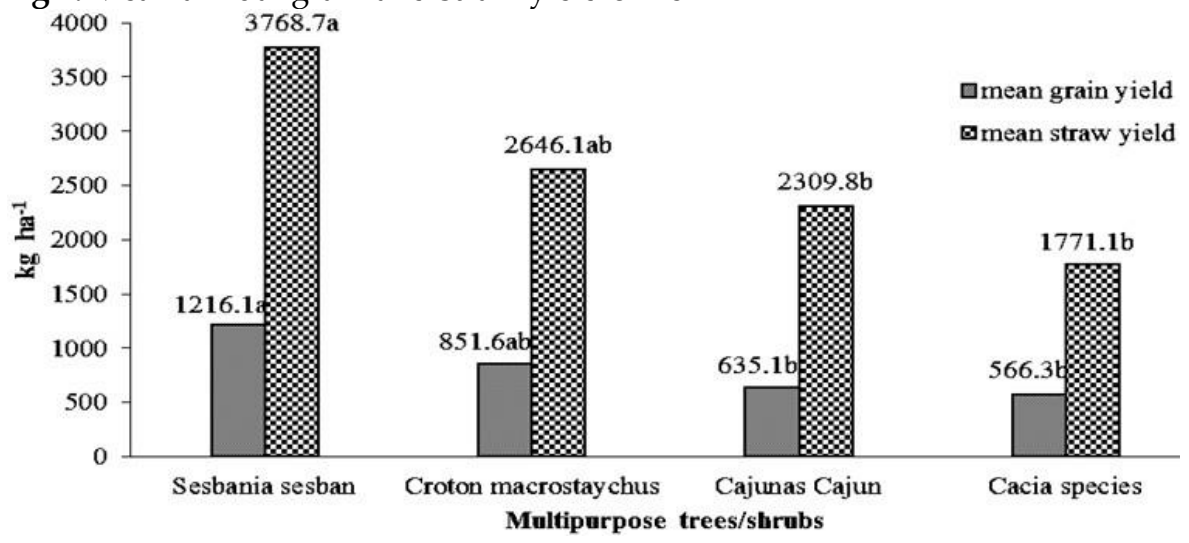

As shown in Fig 1, utilization of Sesbania sesban as green manure increases Teff grain yield by $42 \%, 91 \%$ and $115 \%$ and Teff straw yield by $42 \%, 63 \%$ and $113 \%$ over Croton macrostaychus, Cajuns Cajun and Cacia species, respectively. 


\section{ConClusion AND ReCOMmEndATION}

Growing of Teff in association with $\mathrm{N}$-fixing tree/shrub species in alley cropping agro forestry system had sustained productivity. Mulching or applications of pruning of Sesbania sesban and Croton macrostaychus green leaf biomass to the Teff cropped field enhance grain and straw yield. From the study we concludes that, incorporation Sesbania sesban increases from 91\% - 115\% grain and 63\% - 113\% straw, and Croton macrostaychus increases from $34 \%-50 \%$ grain and $14 \%-49 \%$ straw yield over Cajuns Cajunand Cacia species, respectively. The same experiments revealed that there was higher available phosphorus and total nitrogen content in Sesbania sesban. For this reason, the present study results suggested that supplementing the pruning of Sesbania sesban and Croton macrostaychus on Teff crop farm increases the grain and straw yield of Teff at reasonable level. Further, work is needed to identify other suitable species for alley cropping in the area and also to test other agro forestry technologies. In addition understanding of leaf decomposition rate and nutrient dynamics processes in alley cropping systems.

\section{REFERENCES}

Ahmed, R. (2014). Performance Evaluation of Draught Animal Power Cultivator. Asian Journal Of Applied Science And Engineering, 3(8), 111-117. doi:10.15590/ajase/2014/v3i8/54949

Akonde TP, Leihner DE and Steinmuller N (1996).Alley cropping on an ultisol in sub-humid, Benin. Part I: Long-term effects on maize, cassava and tree productivity. Agroforestry Systems 24:1-12

Chamshama S. A. O, Mugasha G, Kløvstad A., Haveraaen O. and Maliondo S. M. S, 1998. Growth and yield of maize alley cropped with Leucaenaleucocephala and Faidherbiaalbida in Morogoro, Tanzania. Agroforestry Systems 40: $215-225$.

Lawson TL and Kang BT 1990. Yield of maize and cowpea in an alley cropping system in relation to available light. Agriculture for Metrology 52: 347-357

Legesse N., 2002. Erythrinabrucei: Propagation attributes, leaf nutrient concentration and impact on barley grain yield. Agroforestry Systems56: 39-46

Leinhner DE, Ernst-Schaeben R, Akonde' TP and Steinmuller N 1996.Alley cropping on an ultisol in subhumid Benin. II: Changes in crop physiology and tree crop competition. Agroforestry system 34: 13-25

Lulandala LLL, Munishi PKT and Maliondo SMS (1995).Effect of spacing and management regime on Leucaena fodder yield and nutrient removals in alley cropping systems in Tanzania.International Tree Crops Journal 8: 129-137

Mesfes T., 2003. Participatory forestry in practice (literature review) Wondo Genet College of forestry abstract of thesis and research works, Debub University Ethiopia.

Nair P.K.R., 1993. An introduction to agroforestry. Dordrecht, Netherlands, Kluwer Academic Publishers.

Owino, F., Hayombe, P., \& Agong, S. (2014). Spatial Planning Interventions and their Implications on Conservation of Urban Green Spaces. Asian Journal Of Applied Science And Engineering, 3(8), 61-74. doi:10.15590/ajase/2014/v3i8/54485

Stephen R.G liessman, 2000. Agro ecosystem sustainability: Developing practical strategy. CRC.Baca Raton London.

Young A., 1989. Agroforestry for soil conservation.ICRAF (international center for Research in Agroforestry). Nairobi, Kenya.

$$
--0 \text {-- }
$$

